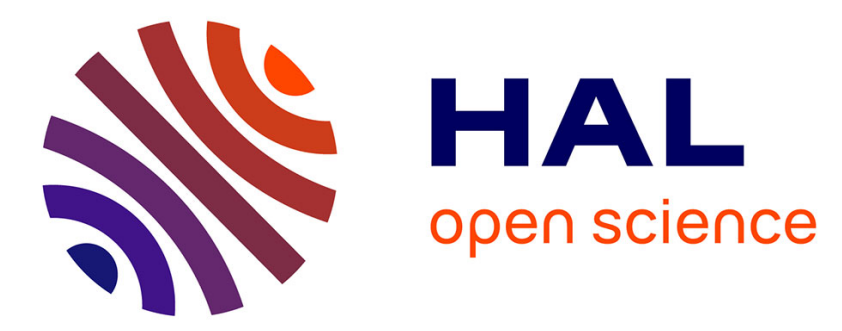

\title{
Hydrogen sulfide inhibits giant depolarizing potentials and abolishes epileptiform activity of neonatal rat hippocampal slices
}

Aleksey V Yakovlev, Evgeniya D Kurmasheva, Rashid Giniatullin, Ilgam

Khalilov, Guzel F Sitdikova

\section{To cite this version:}

Aleksey V Yakovlev, Evgeniya D Kurmasheva, Rashid Giniatullin, Ilgam Khalilov, Guzel F Sitdikova. Hydrogen sulfide inhibits giant depolarizing potentials and abolishes epileptiform activity of neonatal rat hippocampal slices. Neuroscience, 2017, 340, pp.153-165. 10.1016/j.neuroscience.2016.10.051 . hal-01962401

\section{HAL Id: hal-01962401 \\ https://hal-amu.archives-ouvertes.fr/hal-01962401}

Submitted on 20 Dec 2018

HAL is a multi-disciplinary open access archive for the deposit and dissemination of scientific research documents, whether they are published or not. The documents may come from teaching and research institutions in France or abroad, or from public or private research centers.
L'archive ouverte pluridisciplinaire HAL, est destinée au dépôt et à la diffusion de documents scientifiques de niveau recherche, publiés ou non, émanant des établissements d'enseignement et de recherche français ou étrangers, des laboratoires publics ou privés.

\section{(c)(1)}

Distributed under a Creative Commons Attribution| 4.0 International License 


\section{HYDROGEN SULFIDE INHIBITS GIANT DEPOLARIZING POTENTIALS AND ABOLISHES EPILEPTIFORM ACTIVITY OF NEONATAL RAT HIPPOCAMPAL SLICES}

\author{
ALEKSEY V. YAKOVLEV, \\ EVGENIYA D. KURMASHEVA, ${ }^{a}$ RASHID GINIATULLIN, \\ ILGAM KHALILOV ${ }^{\mathrm{a}, \mathrm{c}, \mathrm{d}}$ AND GUZEL F. SITDIKOVA ${ }^{\mathrm{a}}$ \\ ${ }^{a}$ Department of Human and Animal Physiology, Institute of \\ Fundamental Medicine and Biology, Kazan Federal \\ University, 420008 Kazan, Russia \\ ${ }^{\mathrm{b}}$ Cell Biology Laboratory, Department of Neurobiology, A.I. \\ Virtanen Institute for Molecular Sciences, University of \\ Eastern Finland, 70211, Neulaniementie 2, Kuopio, Finland \\ c INMED-INSERM U901, 163, Avenue de Luminy, 13273 \\ Marseille Cedex 09, France \\ ${ }^{d}$ Aix-Marseille University, 163, Avenue de Luminy, 13273 \\ Marseille Cedex 09, France
}

\begin{abstract}
Hydrogen sulfide $\left(\mathrm{H}_{2} \mathrm{~S}\right)$ is an endogenous gasotransmitter with neuroprotective properties that participates in the regulation of transmitter release and neuronal excitability in various brain structures. The role of $\mathrm{H}_{2} \mathrm{~S}$ in the growth and maturation of neural networks however remains unclear. The aim of the present study is to reveal the effects of $\mathrm{H}_{2} \mathrm{~S}$ on neuronal spontaneous activity relevant to neuronal maturation in hippocampal slices of neonatal rats. Sodium hydrosulfide (NaHS) $(100 \mu \mathrm{M})$, a classical donor of $\mathrm{H}_{2} \mathrm{~S}$ produced a biphasic effect with initial activation and subsequent concentration-dependent suppression of network-driven giant depolarizing potentials (GDPs) and neuronal spiking activity. Likewise, the substrate of $\mathrm{H}_{2} \mathrm{~S}$ synthesis L-cysteine (1 $\mathrm{mM}$ ) induced an initial increase followed by an inhibition of GDPs and spiking activity. Our experiments indicate that the increase in initial discharge activity by NaHS is evoked by neuronal depolarization which is partially mediated by a reduction of outward $\mathrm{K}^{+}$currents. The subsequent decrease in the neuronal activity by $\mathrm{H}_{2} \mathrm{~S}$
\end{abstract}

\footnotetext{
${ }^{*}$ Correspondence author. Address: Department of Human and Animal Physiology, Institute of Fundamental Medicine and Biology, Kazan Federal University, Kazan 420008, Kremlevskii Street, 18, Russia.

E-mail addresses: alv.yakovlev@gmail.com (A. V. Yakovlev), harlequin18@gmail.com (E. D. Kurmasheva), rashid.giniatullin@uef. fi (R. Giniatullin), ilgam.khalilov@inserm.fr (I. Khalilov), guzel. sitdikova@kpfu.ru (G. F. Sitdikova).

Abbreviations: 3-MST, 3-mercaptopyruvate sulfurtransferase; ACSF, artificial cerebrospinal fluid; AMPA, $\alpha$-amino-3-hydroxy-5-methyl-4-iso xazolepropionic acid; CAT, cysteine aminotransferase; CBS, cystathionine beta-synthase; CNQX, 6-cyano-7-nitroquinoxaline-2,3di one; CSE, cystathionine gamma-lyase; DAO, d-amino acid oxidase; d-APV, d-2-amino-5-phosphopentanoate; EGTA, ethylene glycol-bis(2aminoethylether)- $N, N, N^{\prime}, N^{\prime}$-tetraacetic acid; GABA, $\gamma$-aminobutyric acid; GDPs, giant depolarizing potentials; $\mathrm{H}_{2} \mathrm{~S}$, hydrogen sulfide; HEPES, 4-(2-hydroxyethyl)-1-piperazineethanesulfonic acid; MUA, multi-unit activity; NaHS, sodium hydrosulfide; NMDA, N-methyl-Daspartate; TEA, tetraethylammonium; TTX, tetrodotoxin.
}

appears to be due to the rightward shift of activation and inactivation of voltage-gated $\mathrm{Na}^{+}$currents, thus preventing network activity. NaHS also reduced $\mathrm{N}$-methyl-D-aspartate (NMDA)-mediated currents, without essential effect on AMPA/kainate or GABA $_{A}$-mediated currents. Finally, $\mathrm{H}_{2} \mathrm{~S}$ abolished the interictal-like events induced by bicuculline. In summary, our results suggest that through the inhibitory action on voltage-gated $\mathrm{Na}^{+}$channels and NMDA receptors, $\mathrm{H}_{2} \mathrm{~S}$ prevents the enhanced neuronal excitability typical to early hippocampal networks. (C) 2016 IBRO. Published by Elsevier Ltd. All rights reserved.

Key words: hydrogen sulfide, neonatal hippocampus, giant depolarizing potentials, membrane potential, interictal-like events, NMDA-mediated currents.

\section{INTRODUCTION}

Hydrogen sulfide $\left(\mathrm{H}_{2} \mathrm{~S}\right)$ has been recently identified as an important intra- and intercellular messenger, regulating various physiological and pathological processes (Kimura, 2010; Hermann et al., 2012a; Wang, 2012). In the central nervous system $\mathrm{H}_{2} \mathrm{~S}$ induces long-term potentiation in the hippocampus (Abe and Kimura, 1996), modulates neuronal excitability of the subfornical organ, the nucleus of the solitary tract (Kuksis et al., 2014; Kuksis and Ferguson, 2015; Malik and Ferguson, 2016) and trigeminal neurons (Feng et al., 2013) and mediates central inhibition of the respiratory rhythm (Chen et al., 2013). In the peripheral nervous system $\mathrm{H}_{2} \mathrm{~S}$ modulates transmitter release as well as exo- and endocytosis of synaptic vesicles in motor nerve endings (Sitdikova et al., 2011; Gerasimova et al., 2013, 2015; Mitrukhina et al., 2013). $\mathrm{H}_{2} \mathrm{~S}$ also exerts neuro-protectant effects by preventing oxidative stress (Kimura and Kimura, 2004) and by increasing glutathione levels (Kimura et al., 2010). Furthermore, $\mathrm{H}_{2} \mathrm{~S}$ participates in the pathophysiology of central nervous system diseases such as epilepsy, stroke, neurodegenerative diseases and hyper-homocysteinemia (Wang, 2012; Luo et al., 2014). Neurotoxic or neuroprotective action of $\mathrm{H}_{2} \mathrm{~S}$ is critically dependent on its concentration and cellular location (Wedmann et al., 2014).

$\mathrm{H}_{2} \mathrm{~S}$ can change neuronal excitability through modulation of $\mathrm{Na}^{+}$channels (Khademullah and Ferguson, 2013; Kuksis and Ferguson, 2015) and different types of $\mathrm{K}^{+}$channels (Pan et al., 2010; Sitdikova 
et al., 2010, 2014; Hermann et al., 2012b, 2015; Malik and Ferguson, 2016; Feng et al., 2013; Mustafina et al., 2015), $\mathrm{Cl}^{-}$channels (Tang et al., 2010) and $\mathrm{Ca}^{2+}$ channels (Sekiguchi et al., 2014; Kuksis and Ferguson, 2015).

Endogenous synthesis of $\mathrm{H}_{2} \mathrm{~S}$ in mammalian tissues occurs mainly from L-cysteine and homocysteine through three enzymes: cystathionine gamma-lyase (CSE), cystathionine beta-synthase (CBS) and 3-mercaptopyruvate sulfurtransferase (3-MST) along with additional contribution of cysteine aminotransferase (CAT) or D-amino acid oxidase (DAO) (Abe and Kimura, 1996; Kimura, 2010; Renga, 2011). CBS is highly expressed in the hippocampus and cerebellum (Abe and Kimura, 1996). CSE is found in the spinal cord and cortex (Diwakar and Ravindranath, 2007). 3-MST/CAT and DAO are expressed in hippocampus, cerebellum and cerebral cortex (Abe and Kimura, 1996; Kimura, 2010; Renga, 2011).

Giant depolarizing potentials (GDPs) are spontaneous synchronized neuronal discharges generated by the hippocampal network in neonatal rats. GDPs play an important role in the development of synaptic connections between cells during intense neuronal growth and synaptogenesis (Ben-Ari et al., 1989). In the developing brain $\gamma$-aminobutyric acid (GABA) is excitatory because neurons exhibit a high intracellular chloride concentration (Ben-Ari et al., 2012). The depolarizing action of GABA, together with that of glutamate underlies the initiation of GDPs (Ben-Ari et al., 1989).

The expression of CBS in the nervous system during the embryonic period is generally low and increases in the late embryonic to the early postnatal period (Enokido et al., 2005; Bruintjes et al., 2014). The significance of this developmental regulation is unknown. A possible role of CBS may comprise a reduction of the homocysteine level which at high concentrations contributes to pathologies of nervous system development (Rosenquist and Finnell, 2001). However, the role of $\mathrm{H}_{2} \mathrm{~S}$ in the hippocampal network maturation remains unknown.

The aim of our study was to investigate the effects of $\mathrm{H}_{2} \mathrm{~S}$ and L-cysteine on spontaneous network neuronal activity and membrane potential of pyramidal neurons in rat hippocampus slices during the first week after birth. We also examined the effects of $\mathrm{H}_{2} \mathrm{~S}$ on voltagedependent $\mathrm{Na}^{+}$currents and $\mathrm{K}^{+}$currents, to highlight the contribution of these currents in the regulation of excitability. In addition we analyzed the effects of $\mathrm{H}_{2} \mathrm{~S}$ on glutamate and GABA receptor-mediated currents of pyramidal neurons. Finally, we studied the effects of $\mathrm{H}_{2} \mathrm{~S}$ on bicuculline-induced interictal-like events in rat hippocampus slices.

\section{EXPERIMENTAL PROCEDURES}

\section{Slice preparation}

Experiments were carried out on brain slices of 84 neonatal Wistar rats (postnatal days (P) 3-7). The work has been performed in accordance with EU Directive 2010/63/EU for animal experiments and all animal-use protocols were approved by the French National
Institute of Health and Medical Research (INSERM, protocol N007.08.01) and Kazan Federal University on the use of laboratory animals (ethical approval by the Institutional Animal Care and Use Committee of Kazan State Medical University N9-2013). Animals were anesthetized by isofluran $(4 \%)$ or were subjected to cryoanesthesia before being decapitated. After isolation, the rat brains were placed into a cooled oxygenated artificial cerebrospinal fluid (ACSF) which contained (in $\mathrm{mM}$ ): $\mathrm{NaCl} 126 ; \mathrm{KCl} 3.5 ; \mathrm{CaCl}_{2} 2.0, \mathrm{MgCl}_{2} 1.3, \mathrm{NaHCO}_{3}$ 25, $\mathrm{NaH}_{2} \mathrm{PO}_{4} 1.25$ and glucose 10, (pH 7.4). Horizontal slices $(400 \mu \mathrm{m}$ thick) were cut using a HM $650 \mathrm{~V}$ vibratome (Microm International, Germany) and kept $1 \mathrm{~h}$ before use in oxygenated ACSF at room temperature, then transferred to the recording chamber and superfused with oxygenated $\operatorname{ACSF}\left(33^{\circ} \mathrm{C}\right)$.

\section{Chemicals}

Chemicals used were: N-methyl-D-aspartate (NMDA; 50-100 $\mu \mathrm{M})$, bicuculline $(10 \mu \mathrm{M}), 6$-cyano-7-nitroquinoxa line-2,3dione (CNQX, 10-40 $\mu \mathrm{M})$, d-2-amino-5phosphopentanoate (d-APV, $40 \mu \mathrm{M})$, CGP55845 (CGP, $2 \mu \mathrm{M}$ ), tetraethylammonium (TEA, $2 \mathrm{mM}$ ), tetrodotoxin (TTX, $1 \mu \mathrm{M})$ and L-cysteine $(0.3 \mathrm{mM})$. All substances except TTX were purchased from Sigma-Aldrich (St. Louis, MO, USA). TTX was purchased from Alomone labs (Jerusalem, Israel). All drugs were dissolved to a final concentration in ASCF and applied to the preparation via a bath perfusion system. Sodium hydrosulfide (NaHS, Sigma-Aldrich, USA) was used as a source of $\mathrm{H}_{2} \mathrm{~S}$. In solution this compound dissociates to give $\mathrm{HS}^{-}$which associates with $\mathrm{H}^{+}$to produce $\mathrm{H}_{2} \mathrm{~S}$. At $37^{\circ} \mathrm{C} 14 \%$ of total sulfide is present as $\mathrm{H}_{2} \mathrm{~S}$ calculated from the Henderson-Hasselbalch equation (Whitfield et al., 2008). The real-time measurements of $\mathrm{H}_{2} \mathrm{~S}$ in the chamber using amperometric sensors indicate a rapid loss of sulfide via $\mathrm{H}_{2} \mathrm{~S}$ volatilization by bubbling with about $50 \% \mathrm{H}_{2} \mathrm{~S}$ loss within $3 \mathrm{~min}$ (DeLeon et al., 2012; Sitdikova et al., 2014). In our experiments NaHS was used at a concentration of $100 \mu \mathrm{M}$ which yields about $14 \mu \mathrm{M} \mathrm{H}_{2} \mathrm{~S}$ in the perfusion system which constantly flows to the recording chamber. Due to volatilization the $\mathrm{H}_{2} \mathrm{~S}$ concentration further decreases by $50 \%$ of the initial level which amounts to approximately $7 \mu \mathrm{M} \mathrm{H} \mathrm{H}_{2} \mathrm{~S}$ in the perfusate. In addition, $\mathrm{H}_{2} \mathrm{~S}$ is quickly bound to slice preparation tissue and undergoes oxidation, as it was shown in the plasma in vivo (Whitfield et al., 2008). This will further decrease the $\mathrm{H}_{2} \mathrm{~S}$ concentration at the target sites by an unknown amount. Stock solutions of $\mathrm{NaHS}$ were prepared immediately before each experiment and kept hermetically sealed in a dark place.

\section{Electrophysiological recording}

Extracellular field potentials and multi-unit activity (MUA) were recorded, from hippocampal slices from the CA3 pyramidal cell layer using tungsten wire electrodes (diameter $50 \mu \mathrm{m}$, California FineWire, Grover Beach, CA, USA) and a low-noise DAM-80 amplifier (WPI, GB; low-pass filter: $0.1 \mathrm{~Hz}$; high-pass filter: $3 \mathrm{kHz} ; \times 1000)$. Spontaneous GDPs were recorded using patch-clamp 
techniques in whole-cell configuration in voltage-clamp mode. Glass microelectrodes were located under visual control by means of an Axio Examiner A1 microscope $(400 \times$, Carl Zeiss, Germany) using differential interference contrast optic.

Patch-clamp amplifier Axopatch 200B (Axon Instruments, Molecular Devices, CA, USA) was employed for signal recordings using a gain of $5 \mathrm{mV} / \mathrm{pA}$ and a band path of $0-2 \mathrm{kHz}$. For whole-cell and cellattached recordings electrodes were prepared from borosilicate glass capillaries with outer and inner diameter of 1.5 and $0.86 \mathrm{~mm}$, respectively (GC150F-15, Clark Electromedical Instruments, UK). Pipettes were filled with either $135 \mathrm{mM}$ cesium methylsulfate or $135 \mathrm{mM}$ potassium gluconate solution. Both electrode solutions also contained $(\mathrm{mM}): \mathrm{CaCl}_{2}$ 0.1, EGTA 1, HEPES 10, NaATP 2 and NaGTP 0.4 (pH 7.25), osmolarity $290 \mathrm{mOsm}$, with the $\mathrm{pH}$ adjusted to 7.3 with $\mathrm{CsOH}$ or $\mathrm{KOH}$. Patch pipettes had a resistance of 4-8 M $\Omega$. The series resistance $\left(R_{\mathrm{s}}\right)$ was not compensated. The liquid junction potential for potassium gluconate-based and cesium gluconate-based internal solution were $15.6 \mathrm{mV}$ and $9.9 \mathrm{mV}$, which were corrected for all data analysis. The membrane resistance was measured in current clamp whole-cell mode by the injection of negative current pulses $(0.02 \mathrm{nA})$ into the neurons.

Current-clamp measurements of the resting membrane potential of CA3 pyramidal cells were performed in cell-attached configuration with null current injected after high-resistance seal formation (>1 GOm) (Mason et al., 2005; Perkins, 2006). The membrane potential $\left(E_{\mathrm{m}}\right)$ was defined as averaging data during 10-min recordings.

The activity of single NMDA channels was recorded using pipettes filled with nominally $\mathrm{Mg}^{2+}$ free ACSF containing NMDA $(10 \mu \mathrm{M})$ and glycine $(10 \mu \mathrm{M})$. In each experiment the activity of NMDA channels was recorded at different voltages from +20 to $-50 \mathrm{mV}$ in a stepwise manner, with steps of $10-20 \mathrm{mV}$. Detection of the opening of single NMDA channels and analysis of the single-channel current amplitudes was performed by means of Axon Software after additional filtration (RC single-pole filter with cut-off frequencies below $200 \mathrm{~Hz}$ ) of the signals, as described earlier (Tyzio et al., 2003; Yakovlev et al., 2013).

$\mathrm{Na}^{+}$currents were studied using a voltage clamp protocol with depolarizing test pulses of $250 \mathrm{~ms}$ at $10 \mathrm{mV}$ increments from -70 to $+20 \mathrm{mV}$ from a holding potential of $-75 \mathrm{mV}$ using cesium methylsulfate-based pipette solution and TEA $2 \mathrm{mM}$ in the external solutions for blocking $\mathrm{K}^{+}$conductance. Current-voltage (I-V) curves were obtained from measurements of peak inward currents. To obtain a steady-state inactivation of $\mathrm{Na}^{+}$currents neurons were kept at prepulses potentials from -80 to $-10 \mathrm{mV}$ for $100 \mathrm{~ms}$ in $5 \mathrm{mV}$ steps followed by test pulses at $-10 \mathrm{mV}$ for $500 \mathrm{~ms}$ (Kuksis and Ferguson, 2015). Using BoltzIV function (OriginLab Corporation, USA) the half-maximum activation ( $\left.V_{\text {half }}\right)$, slope $(k)$, maximal conductance $\left(G_{\max }\right)$, and reversal potentials $\left(V_{\text {rev }}\right)$ for $\mathrm{Na}^{+}$currents were calculated $(+58 \mathrm{mV})$ and the data of current-voltage curves for the peak $\mathrm{Na}^{+}$currents were fitted as follows: $I=G_{\max }\left(V-V_{\text {rev }}\right) /\{1+\exp$ $\left.\left[\left(V-V_{\text {half }}\right) / k\right]\right\}$, where $I$ is the peak transient inward current. Normalized peak currents to maximal transient peak currents $\left(I_{\max }\right)$ were plotted versus prepulse potentials and fitted with the Boltzmann function: $I / I_{\max }=1 /[1-\exp$ $\left.\left(V-V_{50}\right) / k\right]$, where $I_{\max }$ is the maximum current, $V_{50}$ is the membrane potential at the midpoint of the curve, and $k$ is a slope factor.

$\mathrm{K}^{+}$currents were studied using a voltage clamp protocol with depolarizing test pulses at $10 \mathrm{mV}$ increments from -130 to $+50 \mathrm{mV}$ for $250 \mathrm{~ms}$ from a holding potential of $-75 \mathrm{mV}$ using potassium gluconatebased pipette solution and antagonists of NMDA, GABA or AMPA/kainate receptors - d-APV $(40 \mu \mathrm{M}), \mathrm{CNQX}$ $(15 \mu \mathrm{M})$ and bicuculline $(2 \mu \mathrm{M})$, respectively, and TTX ( $1 \mu \mathrm{M}$ for blocking voltage-gated $\mathrm{Na}^{+}$conductance) in external solutions. Current-voltage $(I-V)$ curves were calculated from measurements of current amplitudes at the end of the 250-ms voltage pulses.

Signals were digitized using an AD-converter (Digidata 1440A, Axon Instruments, Molecular Devices, USA) at a frequency of $10 \mathrm{kHz}$. PClamp10.3, Clampfit 10.3 (Axon Instruments, USA), MiniAnalysis 6.03 (Synaptosoft, Decatur, CA, USA) and Origin Pro 2015 (OriginLab Corp, USA) programs were used for data acquisition and analysis. Actions potentials from extracellular recordings were detected by amplitude threshold using MiniAnalysis 6.03 program.

\section{Focal puff drug application}

A pneumatic picopump (PC-820, WPI, USA) was used for puff application of NMDA $(50 \mu \mathrm{M}+50 \mu \mathrm{M}$ glycine for activation of NMDA receptors), glutamate (1 $\mathrm{mM}$, for AMPA/kainate receptors) or GABA $(100 \mu \mathrm{M}$, for GABA receptors) from a glass pipette at a distance of about $50-250 \mu \mathrm{m}$ from the neuronal soma. Pressure was applied at 5-10 psi for durations in the range 50$200 \mathrm{~ms}$. To avoid desensitization of NMDA, GABA or AMPA/kainate receptors agonists substances were applied at 5-min intervals in control with NaHS $(100 \mu \mathrm{M})$ added in the bath solution in 5, 10, 15 min of perfusion and during washout. At the end of each experiment antagonists of NMDA, GABA or AMPA/kainate receptor - d-APV $(40 \mu \mathrm{M})$, CNQX $(15 \mu \mathrm{M})$ and bicuculline $(2 \mu \mathrm{M})$ were applied, respectively. The area under each trace after puff application was calculated by integration using Origin Pro 2015 (OriginLab Corp, USA).

\section{Statistics}

Group measurements are expressed as mean \pm SEM, $n$ - number of animals. All data were checked for normality using the Shapiro-Wilk test and for equal variances using F-test Origin Pro 2015 (OriginLab Corp, USA). Statistical significance between means was calculated using paired $t$-test. In case of heterogeneous variances Welch's correction was performed and two-sample $t$-test was used in Origin Pro 2015 (OriginLab Corp, USA). The level of significance was set at $p \leqslant 0.05$. 


\section{RESULTS}

NaHS and L-cysteine decrease neuronal activity and network-driven GDPs in the hippocampus of neonatal rats.

We first tested the actions of $\mathrm{NaHS}$ and the metabolic precursor of $\mathrm{H}_{2} \mathrm{~S}$, L-cysteine, on the extracellular recorded neuronal activity of immature hippocampus which is characterized by spontaneous network-driven GDPs (Ben-Ari et al., 1989), consisting mainly of GABAergic postsynaptic currents and bursts of MUA (Fig. 1A). All records were obtained from the CA3 region of the hippocampus which is centrally responsible in GDP generation (Khazipov et al., 1997). In control animals, the frequency of GDPs was $0.11 \pm 0.03 c^{-1}$ ( $n=14$ rats). Application of NaHS $(100 \mu \mathrm{M})$ to the bath induced a drastic reduction of GDP frequency to $0.017 \pm 0.01 \mathrm{c}^{-1}$ (16 $\pm 8 \%$; of control; $t(8.5)=5.68, p \leqslant 0.001, n=8)$ within 20 min (Fig. 1A, C). In about $60-70 \%$ of slices an initial short-term increase in GDP frequency to 0.18 $\pm 0.01 \mathrm{c}^{-1} \%$ of control $(163 \pm 31 \%$ of control; $t(5)$ $=4.35, p \leqslant 0.05, n=6$ ) was observed during the first 5 min of $\mathrm{NaHS}$ application (Fig. 1A, C). NaHS also induced two-phase changes of MUA in CA3 pyramidal neurons (Fig. 1A, B, D). NaHS application augmented the number of spikes up to $130 \pm 7 \%$ of control relative to control (from $3.6 \pm 0.5$ to $4.7 \pm 0.9 c^{-1} ; t(7)$ $=-2.37, p \leqslant 0.05, n=8$ ) during the first $5 \mathrm{~min}$. By 20 min of NaHS application the number of action potentials was significantly reduced to $53 \pm 6 \%$ of control $\left(1.9 \pm 0.4 c^{-1} ; t(7)=4.56, p \leqslant 0.01, n=8\right.$; Fig. 1D). Almost complete recovery of GDPs and MUA was observed after an $\sim 30$ - to 45-min washout (Fig. 1A-D). The inhibitory effect of NaHS on GDPs was dosedependent from 1 to $300 \mu \mathrm{M}$, where $300 \mu \mathrm{M}$ of $\mathrm{NaHS}$ completely abolished GDPs within $20 \mathrm{~min}$. As shown in the cumulative dose-response curve of Fig. 1E, fitting the experimental points with the Hill equation gave an $\mathrm{EC}_{50}$ value of $58 \mu \mathrm{M}$. In subsequent experiments we used $\mathrm{NaHS}$ at a concentration of $100 \mu \mathrm{M}$ (effective concentration of $7 \mu \mathrm{M}$, see Experimental procedures/chemicals section).

NaHS effects on spontaneous $\mathrm{GABA}_{A}$-mediated GDPs were supported by whole-cell recordings at a holding potential of $0 \mathrm{mV}$ from CA3 hippocampal pyramidal neurons using low-chloride pipette solution (Cs-based pipette solutions). Bath-applied NaHS $(100 \mu \mathrm{M})$ reduced the amplitude and frequency of spontaneous GDPs progressively and within $20 \mathrm{~min}$ the currents could not be discriminated from the baseline noise (Fig. 1F; $n=6$ ). The effect of $\mathrm{NaHS}$ was reversible and spontaneous GDPs reappeared after a 20 - to $30-\mathrm{min}$ washout in control solution.

In the brain endogenous $\mathrm{H}_{2} \mathrm{~S}$ is produced from L-cysteine and L-homocysteine (Ishigami et al., 2009; Shibuya and Kimura, 2013). L-Cysteine (0.3 mM) induces an increase in the frequency of GDPs up to $235 \pm 43 \%$ of control (from $0.14 \pm 0.02$ up to $0.33 \pm 0.05 c^{-1} ; t(3)$ $=-5.7, p \leqslant 0.05, n=4)$ and MUA up to $171 \pm 31 \%$ of control (from $3.16 \pm 0.2$ to $5.4 \pm 1.15 c^{-1} ; t(3)=-4.3$, $p \leqslant 0.05, n=4)$ without suppression of spontaneous neuronal hippocampal activity. Increasing L-cysteine to
$1 \mathrm{mM}$ simulated the effects of NaHS. During the first 5 min of application the frequency of GDPs was increased by $273 \pm 34 \%$ (from $0.15 \pm 0.02$ to $0.41 \pm 0.05 c^{-1}$; $t(4.2)=-4.8, p \leqslant 0.01, n=5)$ and the spontaneous firing rate by $312 \pm 45 \%$ (from $3.12 \pm 0.5$ to $\left.10.0 \pm 2.4 \mathrm{c}^{-1} ; t(4.3)=-2.8, \quad p \leqslant 0.05, \quad n=5\right)$ compared to control (Fig. 1C, D). Subsequently by $\sim 20 \mathrm{~min}$ a reduction of MUA and GDPs was observed which was $47.5 \pm 9 \%\left(1.5 \pm 0.6 \mathrm{c}^{-1} ; t(4)=3.7, p \leqslant 0.05, n=5\right)$ and $23 \pm 9 \%$ of control $\left(0.04 \pm 0.01 \mathrm{c}^{-1} ; t(4)=10.3\right.$, $p \leqslant 0.001, n=5)$, respectively (Fig. 1C, D).

\section{NaHS and L-cysteine depolarize pyramidal neurons in the CA3 hippocampal region of newborn rats}

In neurons and other excitable cells the value of the resting membrane potential plays a key role in electrogenesis. The effects of NaHS and L-cysteine on the membrane potential of CA3 pyramidal neurons were estimated using cell-attached current-clamp recordings with simultaneous extracellular recording of GDPs and spontaneous MUA at the CA3 layer (Perkins, 2006). Cell-attached current-clamp recordings were used in order to avoid the impact of dialysis of the cytosol by the intra-pipette solution and an artificial conductance (leakage) (Tyzio et al., 2003; Mason et al., 2005). The resting membrane potential was measured from the average of membrane potential recordings in current-clamp mode. Average membrane potential values of -72 $\pm 5 \mathrm{mV}$ ( $n=4$ rats $)$ in CA3 pyramidal cells of P4-P7 animals obtained in our study were close to the values of $-77 \pm 2 \mathrm{mV}$ reported previously (Tyzio et al., 2003). In Fig. 2A an example of a neuron recorded after $\mathrm{NaHS}$ $(100 \mu \mathrm{M})$ application is presented. Administration of $\mathrm{NaHS}$ or L-cysteine induced a rapid depolarization which recovered to baseline after washout. One hundred micromolar NaHS caused a decrease in the membrane potential from $-72 \pm 5 \mathrm{mV}$ to $-42 \pm 10 \mathrm{mV}(t(3)=-3.6$, $p \leqslant 0.05)$ and L-cysteine $(1 \mathrm{mM})$ to $-37 \pm 6 \mathrm{mV}(t(3)$ $=-5.1, p \leqslant 0.05)$ (Fig. 2A, B). During washout after initial hyperpolarization the membrane potential recovered within 20 min (Fig. 2A). Synchronous field recordings from CA3 hippocampus region revealed the initial bursts of action potentials and GDPs, followed by a depression of action potential discharge.

NaHS induced a decrease in the membrane resistance from $1.3 \pm 0.07$ to $0.8 \pm 0.05 \mathrm{G} \Omega$ (t) $(3)$ $=6.71, p \leqslant 0.01, n=4)$ in response to injection of negative currents $(0.02 \mathrm{nA})$, revealing an increase in ion conductance during NaHS application (data not shown).

In a next series of experiments we analyzed the effect of $\mathrm{NaHS}$ on the amplitude of single NMDA channels currents at different holding potentials using cell-attached recordings. This method of the cells resting membrane potential estimation is based on the fact that the reversal potential of the non-selective cationic NMDA channels is close to $0 \mathrm{mV}$ (Nowak et al., 1984) and therefore NMDA currents reverse their polarity at the pipette voltage equal to the resting potential (Tyzio et al., 2003; Yakovlev et al., 2013). When the pipette voltage was equal to $0 \mathrm{mV}$ single NMDA channel openings were manifested as transient, 2- to 4-ms long 


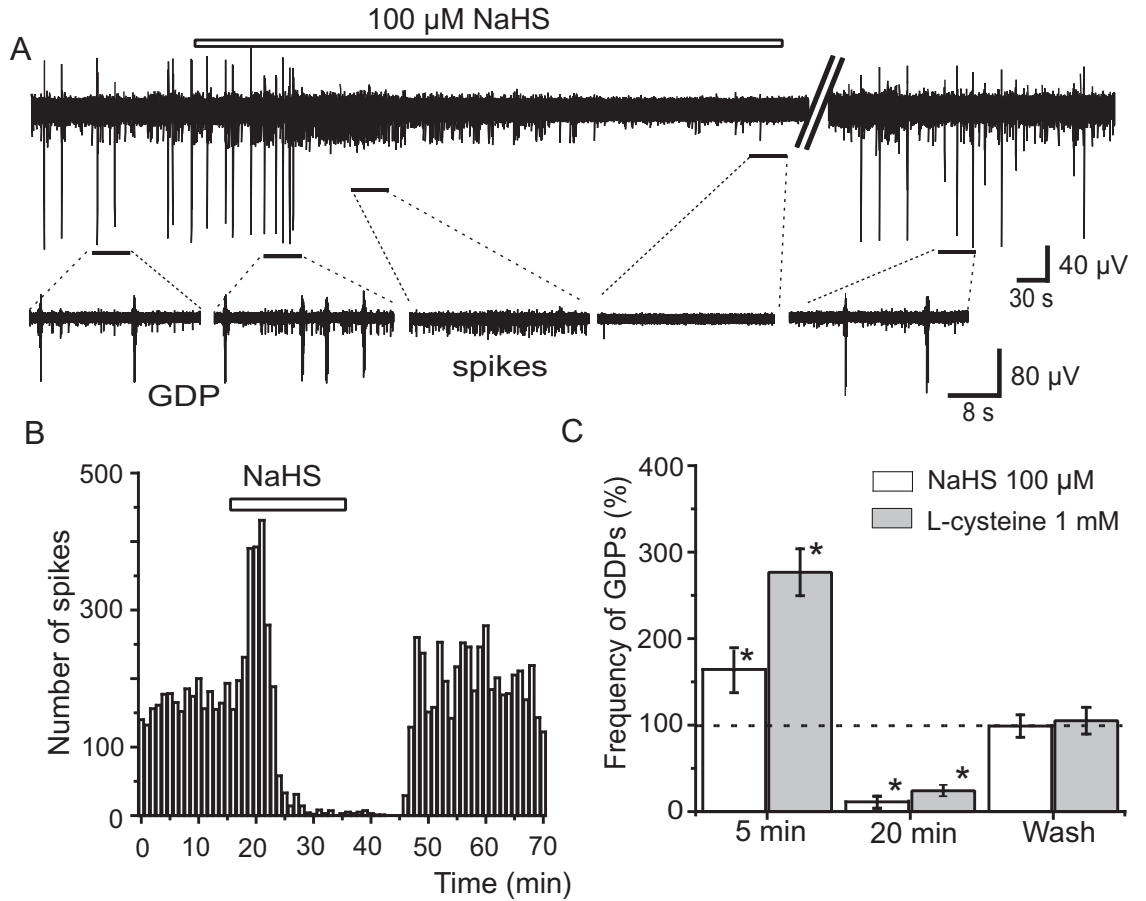

D $\quad E$
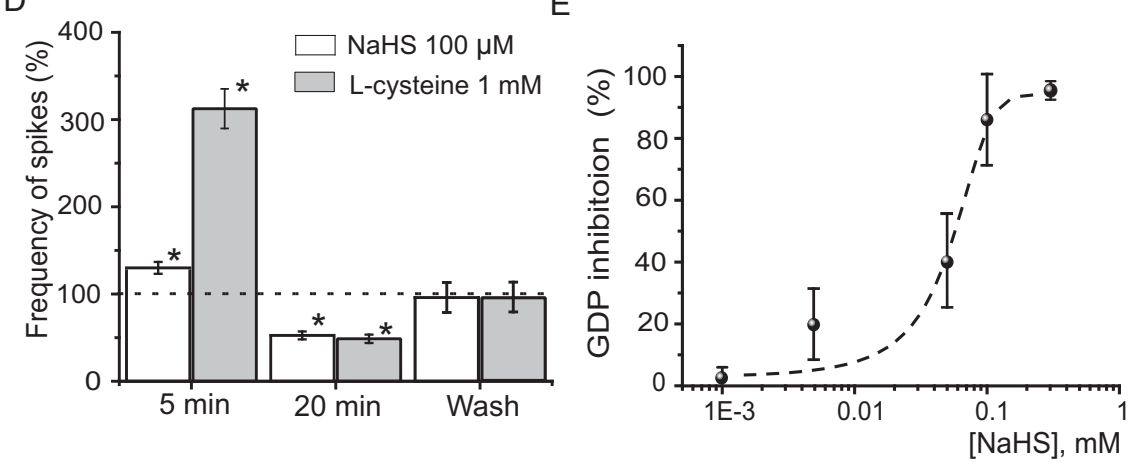

$\mathrm{F}$
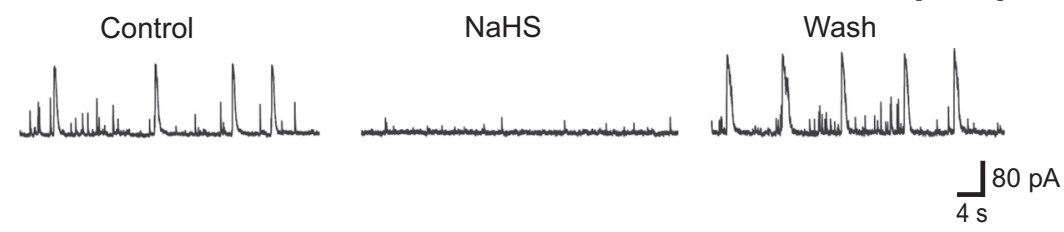

Fig. 1. NaHS and L-cysteine induce biphasic changes of spontaneous neuronal activity in the premature rat hippocampus. (A) Original traces of extracellular recordings of spontaneous GDPs and MUA at P5 before, during and after application of the $\mathrm{H}_{2} \mathrm{~S}$ donor - NaHS (100 $\mu \mathrm{M}$ ) (open horizontal bar indicates the time of application). Parts of the trace marked by filled lines are displayed on an expanded time scale to show changes in spike and GDP frequency. (B) Number of spikes from the trace in $(A)$. Bin $=60 \mathrm{~s}$. The mean \pm SEM of spike frequency (C) and GDPs (D) during first $5 \mathrm{~min}$ and after $20 \mathrm{~min}$ of $\mathrm{NaHS}$ and L-cysteine applications and during washout compared to control (100\% dotted line). (E) NaHS depressed the frequency of GDPs in a concentration-dependent manner. Each point represents the mean value and SEM. Data points were fitted using the Hill equation (the $\mathrm{EC}_{50}$ value was $58 \mu \mathrm{M}$ ) (stippled line). (F) Original trace of spontaneous $\mathrm{GABA}_{\mathrm{A}}$-mediated GDPs in whole-cell mode at P6 during and after application of NaHS. ${ }^{*} p<0.05$ compared to control.

steps of inward current with an amplitude of 4.5 $\pm 1.1 \mathrm{pA}$ ( $n=7$ rats; age of animals P4-P7). It should be noted that in the cell-attached configuration currents are directed opposite to those recorded intracellularly therefore, inward currents in the cell-attached mode are upward. Based on the measurements of amplitudes of single currents flowing through NMDA channels at various voltages applied to the electrode, current-voltage plots were constructed of each cell (Fig. 2C). In control, NMDA currents reversed at an electrode voltage of $-74 \pm 2 \mathrm{mV}$ ( $n=7$ rats). Application of $100 \mu \mathrm{M}$ NaHS shifted the reversal potential to $-44 \pm 5 \mathrm{mV}$ $(t(6)=-6.49, \quad p \leqslant 0.001, \quad n=7)$ (Fig. 2C). Hence, this shift of reversal potential of NMDA currents during NaHS application indicates a depolarization of pyramidal neurons by NaHS.

\section{NaHS induces a rightward shift of activation and inactivation of voltage-gated sodium currents and a decrease of outward potassium currents in pyramidal CA3 neurons.}

Depolarizing effect of NaHS may be mediated by activation of voltagegated $\mathrm{Na}^{+}$currents $\left(I_{\mathrm{Na}}\right)$ as was shown in neurons of the subfornical organ (SFO) or in the nucleus of the solitary track (Kuksis and Ferguson, 2015; Malik and Ferguson, 2016). To evaluate the effect of $\mathrm{NaHS}$ on $I_{\mathrm{Na}}$ whole-cell patch-clamp recordings were used. I Na $_{\text {was induced by depo- }}$ larizing voltage steps according the protocol described in 'Experimental procedures' section and was completely abolished by TTX $(1 \mu \mathrm{M})$ (Fig. 3A). In control conditions a threshold of $I_{\mathrm{Na}}$ activation was between -50 and $-40 \mathrm{mV}$ and a current peak was observed at $-20 \mathrm{mV}$ with amplitudes of $1.5 \pm 0.2 \mathrm{nA}$ ( $n=6$ rats). The voltage of halfmaximal activation ( $\left.V_{\text {half }}\right)$ was -35 $\pm 1 \mathrm{mV}$ and slope $(k) \quad 3.7 \pm 0.6$ $(n=6$; Fig. 3B). After 4- to 6-min incubation $\mathrm{NaHS}$ induced a rightward shift of $I_{\mathrm{Na}}$ activation. Threshold of $I_{\mathrm{Na}}$ activation was between -40 and $-30 \mathrm{mV}$ and current peak was observed at $0 \mathrm{mV}$ with an amplitude of $1.5 \pm 0.2 \mathrm{nA}(n=6$; Fig. 3B). The voltage of $V_{\text {half }}$ shifted to -11 $\pm 2 \mathrm{mV}$ after NaHS application $(t(5)$ $=-15.9, \quad p \leqslant 0.001, n=6)$ and $k$ did not change significantly (4.5 $\pm 0.3 ; t(5)=-2.3, p>0.05, n=6)$. Application of an inactivation step protocol revealed a rightward shift of the inactivation curve in response to NaHS. It was shown that half-maximal inactivation 
A

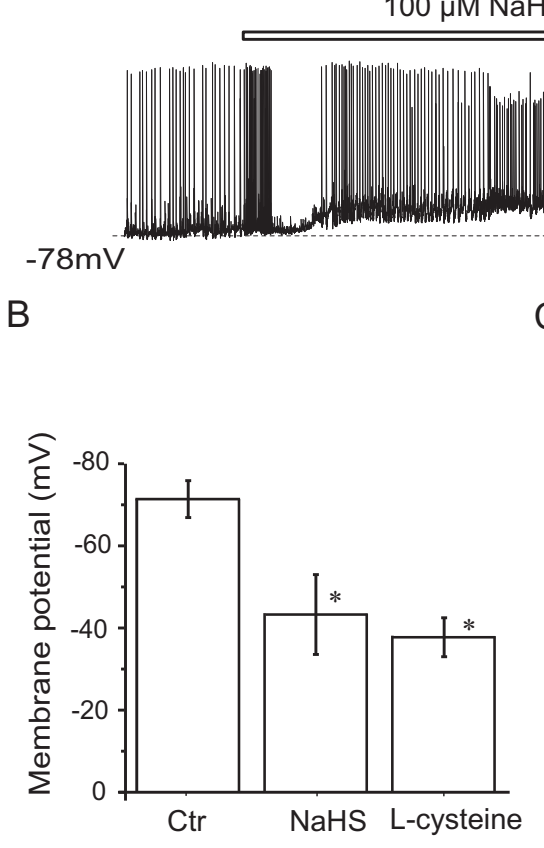

$100 \mu \mathrm{M}$ NaHS
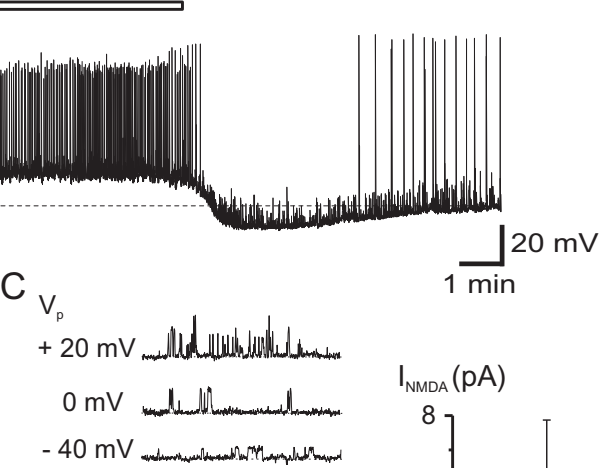

$-70 \mathrm{mV}$

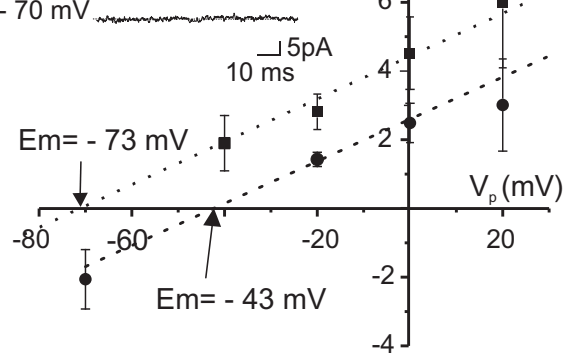

Fig. 2. NaHS and L-cysteine depolarize pyramidal cells in the CA3 region of hippocampus of newborn rats. (A) Example of cell-attached current-clamp recordings from single neurons (P5) demonstrating the depolarizing effect of $100 \mu \mathrm{M}$ NaHS (open horizontal bars indicate the time of application). (B) Bar graph displaying summary results of the membrane potential after application of NaHS $(100 \mu \mathrm{M})$ or L-cysteine $(1 \mathrm{mM})$. (C) Current-voltage relationship of single NMDA channels current recordings in the cell-attached mode. The insert shows examples of original current traces from single NMDA channels at various pipette potentials $\left(V_{p}\right)$ in control conditions.). ${ }^{*} p<0.05$ compared to control.

$\left(V_{50}\right)$ was shifted from $-46 \pm 2 \mathrm{mV}$ in control to -29 $\pm 3 \mathrm{mV}$ after NaHS application $(t(5)=-4.5, p \leqslant 0.01$, $n=6$ ) whereas the slope of the curve did not change significantly (from $5.2 \pm 0.1$ in control to $4.7 \pm 0.2$ in NaHS; $t(7)=1.33, p>0.05, n=6$ ) (Fig. $3 \mathrm{C}$ ). Thus $\mathrm{NaHS}$ did not affect the $I_{\mathrm{Na}}$ amplitude but induced a rightward shift of the activation curve which in turn increases the threshold of action potentials generation and decreases excitability. Bath application of TTX $(1 \mu \mathrm{M})$ did not prevent NaHS-induced depolarization of the membrane potential of neurons.

It was shown that potassium channels in different tissues mediate the effects of $\mathrm{H}_{2} \mathrm{~S}$ on membrane potential and excitability (Feng et al., 2013; Mustafina et al., 2015). NaHS induced a reduction of outward $\mathrm{K}^{+}$ currents at voltages from +5 to $+50 \mathrm{mV}(t(3)=3.56$, $p \leqslant 0.05, n=4$; Fig. 3D, E) during 2 min after donor addition to the bath solution. These effects were prevented by application of TEA $(5 \mathrm{mM})$, a non-specific inhibitor of voltage-gated and $\mathrm{Ca}^{2+}$-activated $\mathrm{K}^{+}$channels before NaHS application (Fig. 3E).

In conclusion, a reduction of $\mathrm{K}^{+}$currents by $\mathrm{NaHS}$ at least partially mediates the depolarization of neurons which underlies the initial increase in firing rate. A rightward shift of activation of $I_{\mathrm{Na}}$ in turn decreases neuronal excitability and prevents network activity.

\section{NaHS decreases NMDA-mediated currents without effects on GABA $_{A^{-}}$and AMPA/kainate- mediated responses}

In neonatal hippocampus during the first postnatal week network-driven GDPs are largely mediated by the depolarizing action of GABA and glutamate through activation of $\mathrm{GABA}_{\mathrm{A}}$ and NMDAreceptors (Leinekugel et al., 1997; Ben-Ari et al., 2012). Therefore, we analyzed the effects of NaHS on $\mathrm{GABA}_{A^{-}}$, NMDA- and AMPA/kainate-mediated currents.

To isolate the effect of $\mathrm{NaHS}$ on $G_{B B A}$-currents, $G A B A_{B}$ receptors were inhibited by CGP $(2 \mu \mathrm{M})$ and AMPA/kainate receptors by CNQX $(15 \mu \mathrm{M})$, and NMDA receptors were blocked by d-APV $(40 \mu \mathrm{M})$. GABA was focally applied $(100 \mu \mathrm{M}$, puff duration $100 \mathrm{~ms}$ ) and whole-cell recordings from pyramidal neurons were performed at a holding potential of $-60 \mathrm{mV}$ using cesiummethylsulfate-based pipette solution. Focal GABA application evoked $G_{A B A}$ receptor-mediated currents (Fig. 4A) which were inhibited by $10 \mu \mathrm{M}$ bicuculline (Fig. 4A, B). Application of $\mathrm{NaHS}(100 \mu \mathrm{M})$ to the bath solution prior to GABA application did not significantly change the area and the amplitude of $\mathrm{GABA}_{\mathrm{A}}$ currents (mean area in $\mathrm{NaHS}$ was 102 $\pm 14 \%$ of control values; $t(3)=-1.1, p>0.05, n=4$; Fig. 4A, B). To examine the effects of NaHS on AMPA/ kainate-currents glutamate $(1 \mathrm{mM}, 50 \mathrm{~ms})$ was applied at a holding potential of $-60 \mathrm{mV}$ in the presence of NMDA and $\mathrm{GABA}_{\mathrm{A} / \mathrm{B}}$ receptors antagonists d-APV $(40 \mu \mathrm{M})$, bicuculline $(10 \mu \mathrm{M})$ and CGP $(2 \mu \mathrm{M})$, respectively (Fig. 4C). NaHS had no effects on AMPA/ kainate currents which were blocked by CNQX $(15 \mu \mathrm{M})$ (mean area in NaHS was $105 \pm 15 \%$ of control values; $t(3)=0.32, p>0.05, n=4$; Fig. 4C, D).

Finally the effect of NaHS on NMDA receptormediated currents at holding potential of $+30 \mathrm{mV}$ was tested (Kimura, 2000; Nardou et al., 2011) in the presence of AMPA/kainate $(C N Q X, 15 \mu \mathrm{M})$ and $\mathrm{GABA}_{\mathrm{A} / \mathrm{B}}$ receptors (bicuculline, $10 \mu \mathrm{M}$ and CGP, $2 \mu \mathrm{M}$ ) antagonists. Focal applications of NMDA $(50 \mu \mathrm{M}, 50 \mu \mathrm{M}$ glycine, $100 \mathrm{~ms}$ ) induced large-amplitude outward currents (Fig. 4E) which were completely blocked by the NMDA receptors antagonist d-APV $(40 \mu \mathrm{M})(\mathrm{Fig} .4 \mathrm{E}, \mathrm{F})$. Bath application of NaHS $(100 \mu \mathrm{M})$ significantly reduced the area of NMDA-induced currents to $69 \pm 5 \% \quad(t(5)$ $=3.17, p \leqslant 0.05, n=6$; Fig. $4 \mathrm{~F}$ ) compared to control $(100 \%)$. These effects did not fully recover after NaHS washout (Fig. 4E, F). 


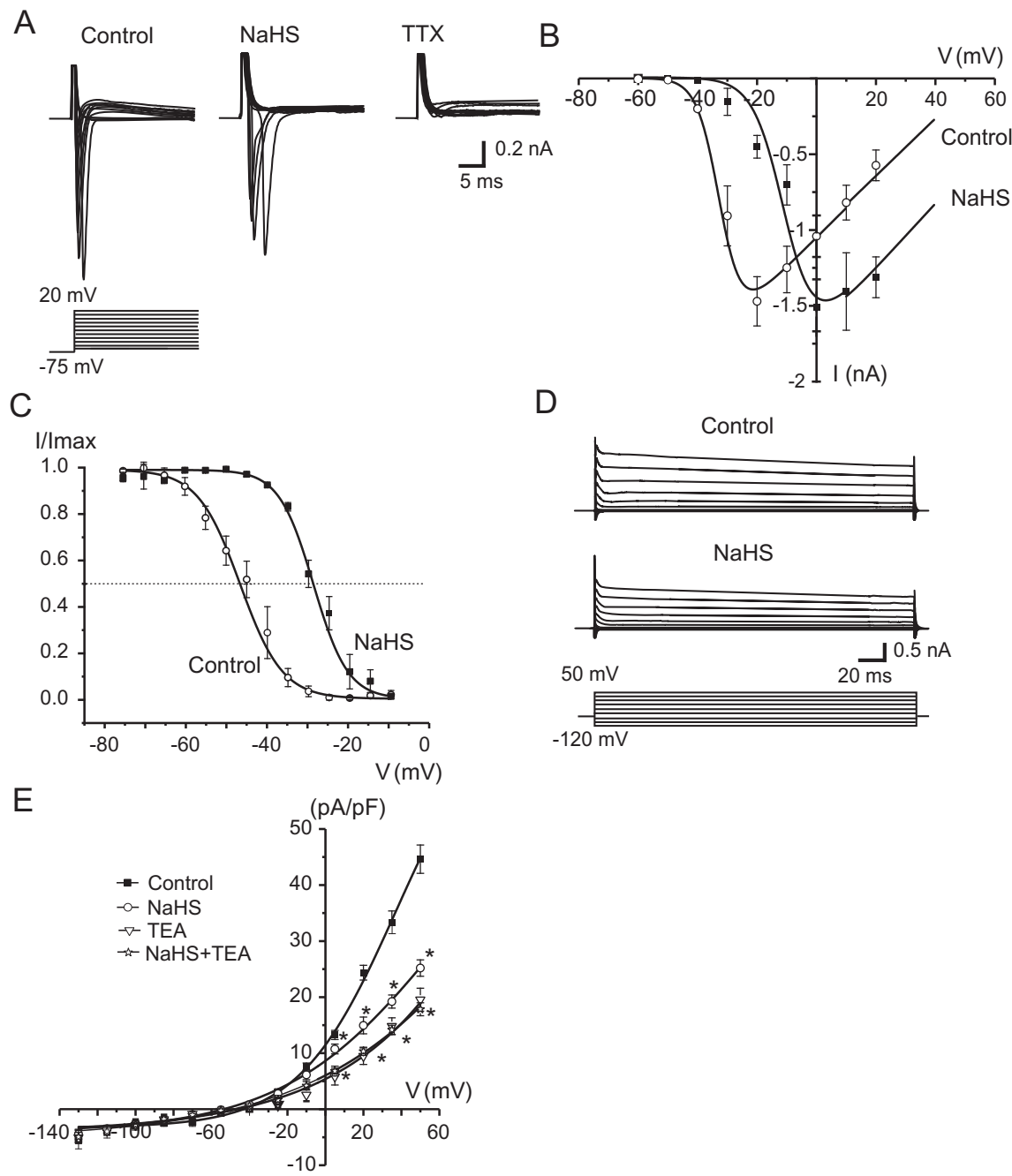

Fig. 3. NaHS effects on voltage-gated sodium currents $\left(I_{\mathrm{Na}}\right)$ and outward potassium currents of CA3 hippocampal neurons during the first week of postnatal development. (A) $I_{\mathrm{Na}}$ elicited by the activation protocol shown at the bottom in control, after addition of $\mathrm{NaHS}(100 \mu \mathrm{M})$ and in presence of TTX $(1 \mu \mathrm{M})$. (B) $I-V$ curve of $I_{\mathrm{Na}}$ evoked by a series of depolarizing pulses from a holding potential of $-75 \mathrm{mV}$ in control (open circles) and in the presence of $100 \mu \mathrm{M} \mathrm{NaHS}$ (filled squares). Data were fitted with a modified Boltzmann function (solid line through data points). (C) The normalized mean inactivation curves plotted against test potentials for control (open circles) and for $\mathrm{NaHS}$ (filled squares); the dotted line indicates the $V_{50}$ value. Data were fitted with a Boltzmann function (solid line). (D) Potassium currents evoked during a series of depolarizing steps from a holding potential of $-70 \mathrm{mV}$ in control and in presence of NaHS $(100 \mu \mathrm{M})$. (E) $I-V$ curves from whole-cell $\mathrm{K}^{+}$current representing current density values $(\mathrm{pA} / \mathrm{pF})$ under control conditions (open circles), after NaHS application (filled squares), in the presence of TEA (open triangles) and TEA $+\mathrm{NaHS}$ (open stars). ${ }^{\star} p<0.05$ compared to control.

In conclusion, NaHS selectively reduces NMDA receptor-mediated currents of neonatal rat hippocampus pyramidal neurons

\section{NaHS inhibits interictal-like events in rat hippocampal slices}

The first two postnatal weeks are very important for brain development and for synaptogenesis, but at the same time this period is characterized by a high incidence of seizures as the result of depolarizing GABA action (Ben-Ari et al., 2012). GABA also exerts an inhibitory action in the immature brain because of a shunting mech- anism due to an increase in membrane conductance (Khalilov et al., 1999). It was shown that in neonatal rat hippocampal slices $\mathrm{GABA}_{\mathrm{A}}$ receptors antagonists block GDPs and induce glutamatergic interictal-like activity (Khalilov et al., 1999, 2003). This activity is similar to the interictal-like epileptiform activity that is observed in adult hippocampal slices after inhibition of $\mathrm{GABA}_{A}$ receptors (Khalilov et al., 1999).

To study the effect of $\mathrm{H}_{2} \mathrm{~S}$ on epileptiform activity in the immature hippocampus (P3-P7), we induced interictal-like events by application of bicuculline (Khalilov et al., 1999). Application of $10 \mu \mathrm{M}$ bicuculline to the bath solution completely blocked GDPs and by $6-10$ min of perfusion elicited interictal-like epileptiform discharges with a frequency of 0.02 $\pm 0.003 c^{-1} \quad(n=5$ rats; Fig. 5A). Further application of $100 \mu \mathrm{M}$ NaHS induced a full and reversible inhibition of epileptiform discharges and reduced the frequency of action potentials (Fig. 5B).

Our results indicate that the biphasic effects of $\mathrm{H}_{2} \mathrm{~S}$ on the physiological pattern of GDPs (transient potentiation in GDPs frequency followed by their inhibition) are due to neuronal depolarization causing network desynchronization. We hypothesize that by this mechanism $\mathrm{H}_{2} \mathrm{~S}$ will be capable of desynchronizing and thus suppressing hyper-synchronous epileptiform discharges.

\section{DISCUSSION}

The main finding of our study is that $\mathrm{H}_{2} \mathrm{~S}$ induces a biphasic effect on network-driven GDPs and neuronal spiking activity in rat neonatal hippocampus, where an initial increase in activity is followed by an inhibition of GDPs and MUA. We have shown that the initial phase is due to a transient depolarization mediated partially by a reduction of outward potassium currents. The second phase is due to a right shift in the activation curve of $\mathrm{Na}^{+}$current thus, decreasing neuronal excitability and preventing network activity. Furthermore, NaHS decreases NMDAmediated currents in neonatal rats without affecting AMPA and GABA responses. Finally, in this preparation $\mathrm{H}_{2} \mathrm{~S}$ abolishes epileptiform activity induced by bicuculline.

At early stages of development in the immature central nervous system spontaneous synaptic activity 
A

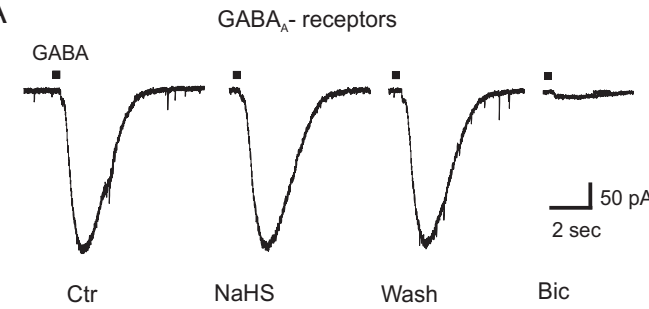

C

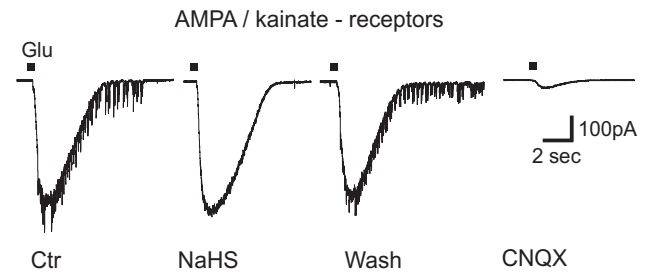

E

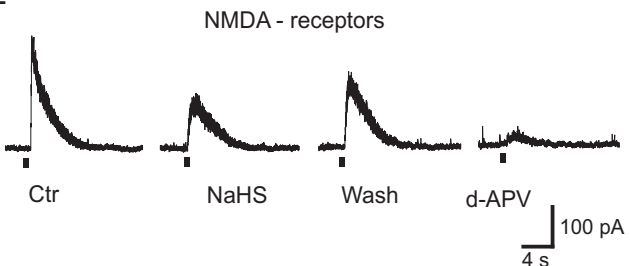

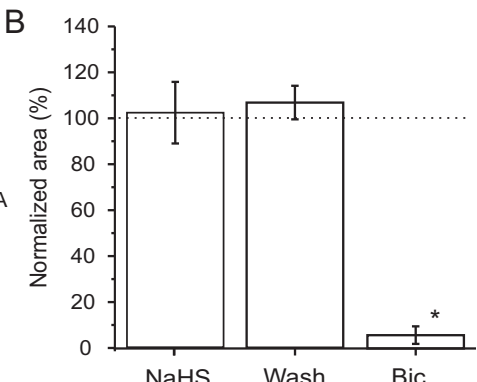

D

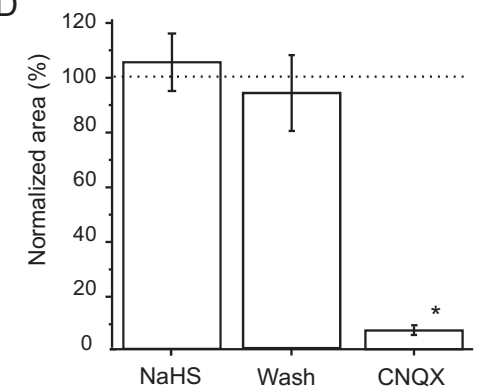

$\mathrm{F}$

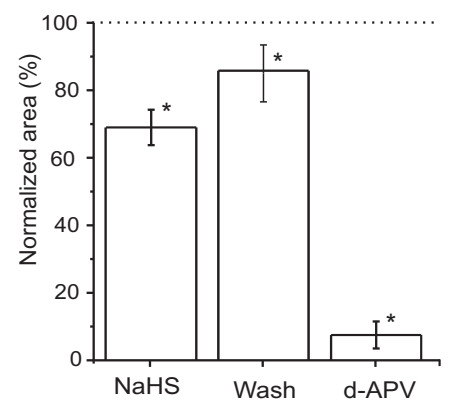

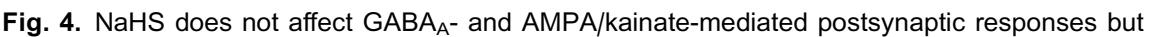
decreases NMDA receptor-mediated currents in CA3 pyramidal cells. Examples of currents evoked in whole-cell voltage-clamp mode at a holding potential of $-60 \mathrm{mV}$ by local GABA (A), glutamate (C) and at a holding potential of $+30 \mathrm{mV}$ NMDA (E) applications (black bars) in the presence of $100 \mu \mathrm{M} \mathrm{NaHS}$ and after washout. Application of inhibitors of $\mathrm{GABA}_{\mathrm{A}}$ - (bicuculline), AMPA/kainate - (CNQX) and NMDA receptors (dAPV) completely suppressed postsynaptic responses. The mean \pm SEM of normalized area GABA (B), AMPA/kainate (D) and NMDA receptor-mediated currents in the presence of $100 \mu \mathrm{M}$ NaHS and after NaHS washout compared to control (dotted line). Ctr - control. ${ }^{*} p<0.05$.

regulates neuronal survival and proliferation, migration, synaptogenesis (Ben-Ari et al., 1989). Spontaneous network-driven GDPs are generated in rat hippocampal slice preparations during the first postnatal week (Ben-Ari et al., 1989). In our study we found that NaHS - a $\mathrm{H}_{2} \mathrm{~S}$ donor - caused initial activation and subsequent suppression of GDPs and MUA in CA3 hippocampal neurons in a reversible manner during first postnatal week. The inhibitory NaHS effect was concentration-dependent from $1 \mu \mathrm{M}$ to $300 \mu \mathrm{M}$ with an $\mathrm{EC}_{50}$ of $58 \mu \mathrm{M}$ which corresponds to an effective $\mathrm{H}_{2} \mathrm{~S}$ concentration about $4 \mu \mathrm{M}$ taking in consideration the evaporation of $\mathrm{H}_{2} \mathrm{~S}$ during bubbling in the perfusion system (see 'Experimental procedures' section; DeLeon et al., 2012; Sitdikova et al., 2014). NaHS at a concentration of $100 \mu \mathrm{M}$ yields about $7 \mu \mathrm{M} \mathrm{H}_{2} \mathrm{~S}$ which is close to endogenous $\mathrm{H}_{2} \mathrm{~S}$ concentrations measured in mammalian tissues (from $10 \mathrm{nM}$ to $3 \mu \mathrm{M}$, Furne et al., 2008; Ishigami et al., 2009) which probably is responsible for physiological actions and does not induce deleterious effects (Wedmann et al., 2014). Indeed in isolated cells $0.1 \mathrm{mM} \mathrm{Na} \mathrm{Na}_{2} \mathrm{~S}$ did not induce the changes of the mitochondrial membrane potential and decreased superoxide anion formation. Only higher doses of $\mathrm{H}_{2} \mathrm{~S}(0.5 \mathrm{mM})$ caused oxidative stress in the cells (Wedmann et al., 2014). Moreover, $\mathrm{H}_{2} \mathrm{~S}$ can even protect mitochondria especially during ischemia-reperfusion injury (Elrod et al., 2007). Concentrations used in our study may reflect the increase in local changes of $\mathrm{H}_{2} \mathrm{~S}$ level in response to increase in endogenous release during physiological conditions. In this case the low basal concentration of $\mathrm{H}_{2} \mathrm{~S}$ in brain would provide the ability of $\mathrm{H}_{2} \mathrm{~S}$ to regulate cellular functions (Furne et al., 2008) and in experimental conditions micro-molar doses of $\mathrm{H}_{2} \mathrm{~S}$ are able to activate cellular signaling before its level decreases (Tang et al., 2010).

First evidence of a neuromodulatory role of $\mathrm{H}_{2} \mathrm{~S}$ in the rat hippocampus was obtained by Abe and Kimura (1996), where NaHS suppressed field excitatory postsynaptic potentials in the CA1 region of hippocampal slices. $\mathrm{H}_{2} \mathrm{~S}$-producing enzymes CBS, 3-MST/CAT or DAO are highly expressed in the hippocampus (Abe and Kimura, 1996; Enokido et al., 2005; Kimura, 2010; Renga, 2011; Bruintjes et al., 2014) and their activity can be modulated by different factors such as $S$-adenosyl methionine (SAM), glutathionylation, nitric oxide, carbon monoxide and $\mathrm{Ca}^{2+}$ (Kimura, 2010). The substrate of $\mathrm{H}_{2} \mathrm{~S}$ synthesis L-cysteine at a concentration of $1 \mathrm{mM}$ (Dominy and Stipanuk, 2004) causes similar effects to NaHS on MUA and GDPs, however, the first excitatory phase was much more pronounced compared to NaHS. The initial excitatory effect of L-cysteine may result from its direct activation of NMDA receptors or by increasing GABA release from interneurons which has been observed in the presence of sulfur-containing amino acids (McBean, 2007). This suggestion is supported by the fact that a smaller concentration of $0.3 \mathrm{mM}$ L-cysteine displayed only excitatory action in our experiments. At the same time NaHS at low concentrations $(1-50 \mu \mathrm{M})$ acts only to depress network activity. It is well known that high doses of L-cysteine produced excitotoxic damage in different tissue especially in central nervous system by activation of NMDA receptors (Puka-Sundvall et al., 1995; Janaky et al., 2000), however, this neurotoxic effect occurs only during long-term exposure of tissue to 
high concentration of L-cysteine (more than 2-3 h) (Olney et al., 1990). At the same time L-cysteine is a precursor for glutathione synthesis in neurons and may thus be involved in neuroprotection (Shibuya et al., 2013). LCysteine at a concentration more than $1 \mathrm{mM}$ is usually used as a substrate of $\mathrm{H}_{2} \mathrm{~S}$ synthesis in different tissues, including brain and basal $\mathrm{H}_{2} \mathrm{~S}$ synthesis was decreased by CBS inhibitors (Abe and Kimura, 1996; Furne et al., 2008; Linden et al., 2008; Martin et al., 2010). It was suggested that $1 \mathrm{mM}$ L-cysteine in addition to its excitatory action on NMDA receptors also serves as a substrate for $\mathrm{CBS}$ and increases $\mathrm{H}_{2} \mathrm{~S}$ synthesis. Neurotoxic effects of L-cysteine appear unlikely in our experiments as we apply L-cysteine only for 20 min (short-term application) and its effect was fully reversible.

The effects of $\mathrm{H}_{2} \mathrm{~S}$ on MUA and GDPs may be linked to changes in cell excitability by its direct action on ion channels and receptors. Actually a number of studies

A
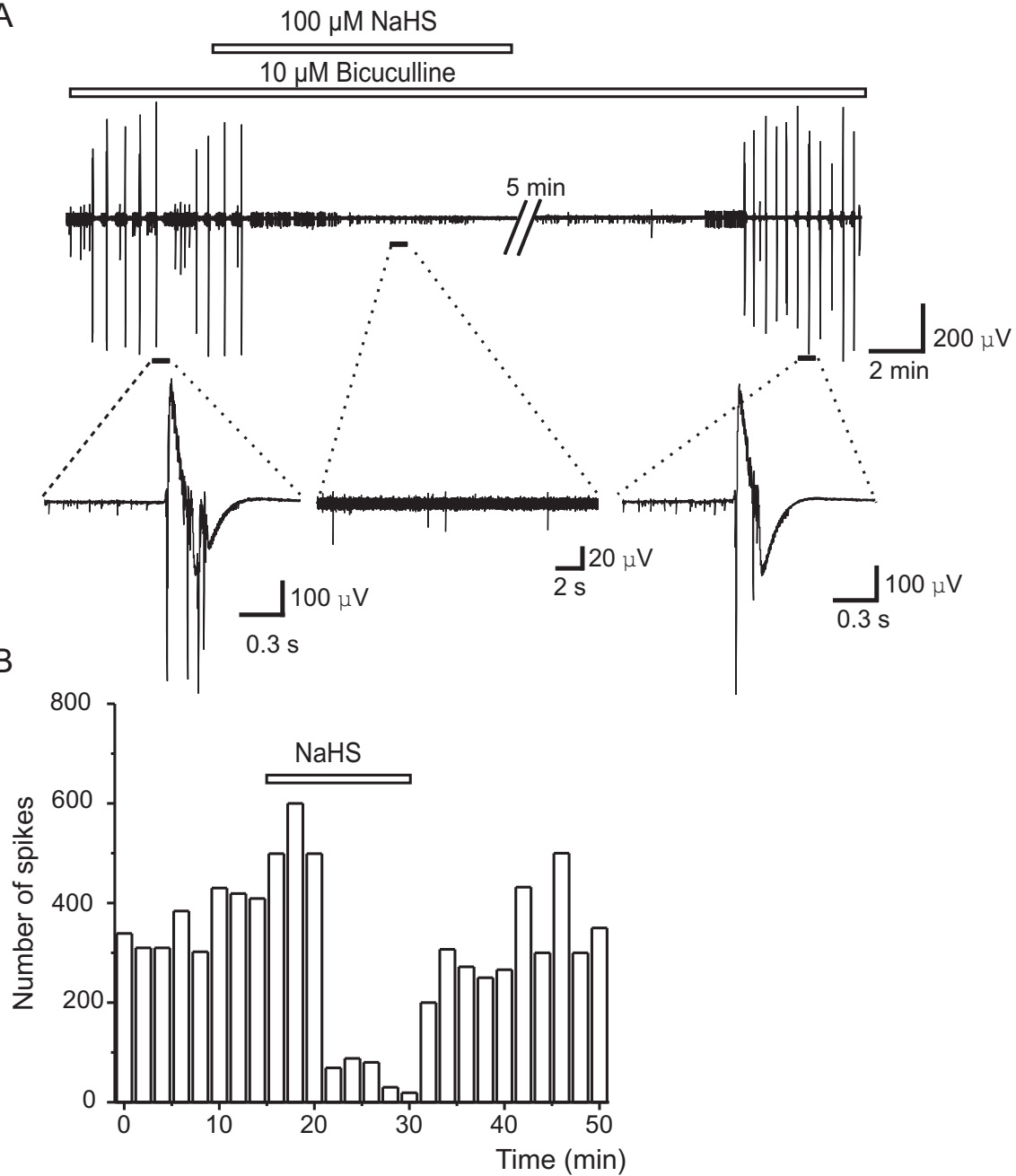

Fig. 5. The $\mathrm{H}_{2} \mathrm{~S}$ donor - NaHS blocks the bicuculline $(10 \mu \mathrm{M})$-induced interictal-like events of neonatal rat hippocampal slices (P7). (A) Extracellular recording of spontaneous interictal-like events in the presence of $\mathrm{GABA}_{\mathrm{A}}$ receptors antagonist. Application of $100 \mu \mathrm{M} \mathrm{NaHS}$ reversibly inhibited interictal-like events and reduced the frequency of spikes. The parts of traces in (A) marked with arrows are displayed on an expanded time scale. (B) Plot of number of spikes taken from the trace (A) before, during and after NaHS application in the presence of bicuculline (open horizontal bar indicates the time of application). Bin $=120 \mathrm{~s}$. have shown that NaHS induces hyperpolarization or depolarization of excitable cells. Activation of $\mathrm{K}_{\mathrm{ATP}}$ channels mediates $\mathrm{H}_{2} \mathrm{~S}$-induced membrane hyperpolarization and decrease of growth hormone release in rat pituitary $\mathrm{GH} 3$ cells (Mustafina et al., 2015), the inhibitory action of $\mathrm{H}_{2} \mathrm{~S}$ on the breathing cycle in medullar neurons of neonatal rats (Chen et al., 2013) and during hypoxic injure in the medullar respiratory center (Pan et al., 2010). On the other hand $\mathrm{H}_{2} \mathrm{~S}$ induced depolarization of paraventricular neurons of the hypothalamus (Khademullah and Ferguson, 2013), trigeminal neurons (Feng et al., 2013) and neurons of the subfornical organ (Kuksis et al., 2014; Kuksis and Ferguson, 2015).

In our experiments using NMDA-channels as membrane potential sensors together with cell-attached current-clamp recordings for analysis of membrane potential (see 'Experimental procedures' section) we found that NaHS $(100 \mu \mathrm{M})$ and L-cysteine $(1 \mathrm{mM})$ induced drastic depolarization of CA3 hippocampal pyramidal neurons of neonatal rats. Depolarization of pyramidal neurons may underlie the initial excitatory effect of NaHS. However, prolonged depolarization will produce inactivation of $\mathrm{Na}^{+}$ channels and suppression of ongoing electrical and synaptic activity as previously shown in striatal spiny neurons after ischemia (Calabresi et al., 1999). Elevated $\mathrm{Na}^{+}$influx may induce a decrease in the membrane potential, however, this effect was not prevented by TTX in our experiments and similar results were obtained also in other studies (Kuksis and Ferguson, 2015; Malik and Ferguson, 2016). It was also shown the NaHS at concentrations of 1 and $10 \mathrm{mM}$ increased $I_{\mathrm{Na}}$ in neurons of entorhinal cortex and subfornical organ (Luo et al., 2014; Kuksis and Ferguson, 2015). In our preparation NaHS induced a rightward shift of activation and inactivation curves of $I_{\mathrm{Na}}$ without affecting the current amplitude. The mechanism by which $\mathrm{H}_{2} \mathrm{~S}$ modulates ion channel activity may relate to redox modification of channels proteins (Sitdikova et al., 2010; Tang et al., 2010). Indeed, the voltage dependence of activation and inactivation and the amplitude of $I_{\mathrm{Na}}$ depend on thiol-reducing agents (Evans and Bielefeldt, 2000). The absence of NaHS effect on $I_{\mathrm{Na}}$ peak can be explained by the low concentration used in our study $(100 \mu \mathrm{M})$ and the peculiarities of expression and regulation of $\mathrm{Na}^{+}$channels in different brain regions during ontogenesis (Costa, 1996). 
Hence, depolarization of hippocampal neurons appears not related to $\mathrm{Na}^{+}$influx during $\mathrm{H}_{2} \mathrm{~S}$ application. A possible mechanism which could explain depolarization may involve inhibition of different types of $\mathrm{K}^{+}$channels, including inwardly rectifying $\mathrm{K}^{+}$(Kir)channels, voltage-gated $\mathrm{K}^{+}$channels, $\mathrm{Ca}^{2+}$-activated $\mathrm{K}^{+}$channels or two-pore or leak $\mathrm{K}^{+}$-channels, which by decreasing $\mathrm{K}^{+}$efflux diminish their contribution to hyperpolarization and hence cause depolarization. Indeed in the paraventricular nucleus of the hypothalamus $\mathrm{H}_{2} \mathrm{~S}$-evoked depolarization of neurons was suggested to result from inhibition of $\mathrm{K}^{+}$currents (Khademullah and Ferguson, 2013). In neurons of rat trigeminal ganglion the increased excitability induced by $\mathrm{H}_{2} \mathrm{~S}$ appears mediated by suppression of A-type $\mathrm{K}^{+}$currents (Feng et al., 2013). In contrast, in neurons of subfornical organ no effects of $\mathrm{H}_{2} \mathrm{~S}$ on $\mathrm{K}^{+}$currents were observed (Kuksis and Ferguson, 2015). Moreover, a large number of studies reported an activating effect of $\mathrm{H}_{2} \mathrm{~S}$ on different $\mathrm{K}^{+}$currents, (in particular on $\mathrm{Ca}^{2+}$ activated $\mathrm{BK}$ channels) (Sitdikova et al., 2010, 2014; Tang et al., 2010; Mustafina et al., 2015) which induces hyperpolarization of neurons (Chen et al., 2013; Malik and Ferguson, 2016). In our experiments we observed a reduction of outward $\mathrm{K}^{+}$ currents which was prevented by TEA. Such a mechanism may partially underlie the depolarization and increased neuronal excitability caused by $\mathrm{H}_{2} \mathrm{~S}$. On the other hand in the nucleus of the solitary tract it was shown that NaHS (5-10 mM) induced an inward current which underlies the depolarization and this current was not voltage sensitive (Malik and Ferguson, 2016). It was suggested that either ion transporters or ion channels without voltage sensitivity were responsible for the depolarization. $\mathrm{Na}^{+} / \mathrm{K}^{+}$-ATPase may be one of the targets of $\mathrm{NaHS}$. However, the concentration of NaHS used in our study unlikely inhibits cell energy production (Erb and Althaus, 2014). Moreover, a decrease in the ATP production would activate of K(ATP) channels and induce hyperpolarization.

We cannot exclude the inhibitory effect of $\mathrm{NaHS}$ on $\mathrm{Na}^{+} / \mathrm{K}^{+}$-ATPase although the data about the direct inhibitory effect of NaHS on this pump is rare. An inhibitory effect of $\mathrm{NaHS}(1 \mathrm{mM})$ on $\mathrm{Na}^{+} / \mathrm{K}^{+}$-ATPase was shown in Xenopus lung epithelia (Erb and Althaus, 2014) and an indirect action of $\mathrm{NaHS}$ on $\mathrm{Na}^{+} /$ $\mathrm{K}^{+}$-ATPase activity was shown in renal tubular epithelial cells where $\mathrm{H}_{2} \mathrm{~S}$ activates epidermal growth factor receptors and causes subsequent endocytosis of $\mathrm{Na}^{+} / \mathrm{K}^{+}$-ATPase (Ge et al., 2014). In neurons of frog sympathetic ganglion where $\mathrm{NaHS}$ induces reversible depolarization $\mathrm{Na}^{+} / \mathrm{K}^{+}$ATPase activity in the presence of sulfide was not different to control (Reiffenstein et al., 1992).

In our experiments we revealed the decrease in membrane resistance during $\mathrm{H}_{2} \mathrm{~S}$ application indicates activation of an unknown conductance which may be involved in the depolarizing action of $\mathrm{H}_{2} \mathrm{~S}$ as was also shown in paraventricular nucleus of the hypothalamus (Khademullah and Ferguson, 2013) and the nucleus of the solitary tract (Malik and Ferguson, 2016).

We tested the hypothesis whether the depression of GDPs in response to $\mathrm{H}_{2} \mathrm{~S}$ may result from its direct action on GABA and/or glutamate receptors underlying GDPs generation. Focal application of GABA, AMPA/ kainate or NMDA receptors agonists revealed that only NMDA receptor-mediated currents were affected by $\mathrm{H}_{2} \mathrm{~S}$. We found a decrease in the amplitude and area of NMDA receptor-mediated currents. This result suggests at least some contribution to the suppression of GDPs induced by $\mathrm{H}_{2} \mathrm{~S}$. Our results are controversial to the data obtained in the studies of Abe and Kimura (1996) where $\mathrm{H}_{2} \mathrm{~S}$ in a concentration-dependent manner stimulated NMDA receptor-mediated currents in CA1 region of hippocampal neurons of 2- to 3-week-old rats by enhancing the sensitivity of NMDA receptors to glutamate. However, for inducing inward currents $A b e$ and Kimura used a different protocol - bath application of $20 \mu \mathrm{M}$ NMDA for $90 \mathrm{~s}$ without blocking $\mathrm{GABA}_{\mathrm{A}}$ and $G_{A B A}$ receptors. Furthermore, studies using NR1 and NR2A NMDA receptors subunits expressed in Xenopus oocytes showed that NaHS decreased the onset time of NMDA responses without changing of their amplitude and this effect was mediated by the production of CAMP (Kimura, 2000). However, it should be noted that at early postnatal development of the hippocampus in rodent brain principal neurons are abundant of NR2B subunits compared to mature neurons in the adult brain (Köhr, 2006). During the first postnatal week in hippocampus NMDA receptors are composed of NR1-NR2B subunits and of NR1, NR2A, and NR2B in the adult brain (Chang et al., 2009). Thus, in our conditions NMDA receptors probably mainly contain NR2B subunits which can explain the differences to previous studies.

At early stages of the brain development hyperexcitability of neurons may increase the probability of seizure-like events (Ben-Ari et al., 2012). In this respect $\mathrm{H}_{2} \mathrm{~S}$ may play a protecting role supporting the inhibitory/ excitatory balance in the developing brain. This suggestion is supported by the fact that the $\mathrm{H}_{2} \mathrm{~S}$-producing enzyme levels in the nervous system are developmentally regulated and the expression level of CBS and 3-MST increases from the late embryonic to the early postnatal period (Enokido et al., 2005). This assumes that CBS and 3MST are involved in the growth and maturation of neural networks.

Deficiency of CBS leads to hyper-homocysteinemia, a condition associated with elevated plasma homocysteine which is known as a risk factor for several neurological diseases, such as cognitive impairment, dementia or epilepsy (Mattson and Shea, 2003). High homocysteine level results in neural tube defects during CNS development in most animal models (Rosenquist and Finnell, 2001). Therefore, CBS might exert protection of neurons by reducing homocysteine concentrations and by producing $\mathrm{H}_{2} \mathrm{~S}$, which was shown to protect neurons from glutamate toxicity (Kimura and Kimura, 2004) by increasing the glutathione level (Kimura et al., 2010) and inhibition of hypoxia-induced apoptosis in cultured hippocampal neurons (Luo et al., 2012).

A protective role of $\mathrm{H}_{2} \mathrm{~S}$ was shown in rat models of recurrent febrile seizure (Han et al., 2005) which is the most common seizure type in children, often causing hippocampal damage. The expression of CBS in the hip- 
pocampus and the plasma level of $\mathrm{H}_{2} \mathrm{~S}$ were dramatically increased by recurrent febrile seizures which may be a compensatory response to suppress neuronal hyperexcitability and thus diminish the neuronal damage in the hippocampus (Han et al., 2005). Our experiments support this notion by the finding of a complete depression of bicuculline-induced interictal-like activities in the neonatal rat hippocampus by NaHS which can be explained by network desynchronization due to depolarization of neurons. Our results are not in accordance with the results of Luo et al. (2014) where $\mathrm{H}_{2} \mathrm{~S}$ aggravated both pentylenetetrazole - as well as pilocarpine-induced seizure-like events in rats (postnatal 15-25 days), whereas both low $\mathrm{Mg}^{2+} /$ high- $\mathrm{K}^{+}$- and 4-aminopyridineinduced seizure-like events had shorter latency after preliminary $\mathrm{H}_{2} \mathrm{~S}$ treatment of brain slices. However, in ûin vitroý experiments these authors recorded the activity of single cells without analysis of the network activity (Luo et al., 2014). Hence, the differences may be explained by the different protocols used and also may reflect agedependent effects of $\mathrm{H}_{2} \mathrm{~S}$.

\section{CONCLUSION}

Our experiments reveal a potential neuromodulatory and neuroprotective role of $\mathrm{H}_{2} \mathrm{~S}$ in the developing nervous system by regulation of hippocampal neuronal excitability, which is supported by our finding that $\mathrm{H}_{2} \mathrm{~S}$ completely depressed epileptiform activity in the hippocampus of neonatal rats. On the other hand excessive $\mathrm{H}_{2} \mathrm{~S}$ production induces inhibition of neuronal activity which may have deleterious effects on neonatal brain development. Our results extend the knowledge on the physiological and pathophysiological functions of $\mathrm{H}_{2} \mathrm{~S}$ in the immature brain and indicate that $\mathrm{H}_{2} \mathrm{~S}$ associated signaling shall be targeted for the treatment of developmental disorders.

\section{CONFLICT OF INTEREST}

The authors declare that there is no conflict of interests regarding the publication.

Acknowledgments-The work was supported by Russian Science Foundation [grant No. 14-15-00618]. The authors are grateful to Dr. Anton Hermann, Dr. Karin Aubrey and Dr. Rustem Khazipov for useful suggestions.

\section{REFERENCE}

Abe K, Kimura H (1996) The possible role of hydrogen sulfide as an endogenous neuromodulator. J Neurosci 16:1066-1071.

Ben-Ari Y, Cherubini E, Corradetti R, Gaiarsa JL (1989) Giant synaptic potentials in immature rat CA3 hippocampal neurones. $J$ Physiol 416:303-325.

Ben-Ari Y, Khalilov I, Kahle KT, Cherubini E (2012) The GABA excitatory/inhibitory shift in brain maturation and neurological disorders. Neuroscience 18:467-486.

Bruintjes JJ, Henning RH, Douwenga W, van der Zee EA (2014) Hippocampal cystathionine beta synthase in young and aged mice. Neurosci Lett 563:135-139.

Calabresi P, Marfia GA, Centonze D, Pisani A, Bernardi G (1999) Sodium influx plays a major role in the membrane depolarization induced by oxygen and glucose deprivation in rat striatal spiny neurons. Stroke 30:171-179.

Chang LR, Liu JP, Zhang N, Wang YJ, Gao XL, Wu Y (2009) Different expression of NR2B and PSD-95 in rat hippocampal subregions during postnatal development. Microsc Res Technol 72: $517-524$.

Chen L, Zhang J, Ding Y, Li H, Nie L, Yan X, Zhou H, Zheng Y (2013) KATP channels of parafacial respiratory group ( $\mathrm{pFRG}$ ) neurons are involved in $\mathrm{H}_{2} \mathrm{~S}$-mediated central inhibition of respiratory rhythm in medullary slices of neonatal rats. Brain Res 1527:141-148.

Costa PF (1996) The kinetic parameters of sodium currents in maturing acutely isolated rat hippocampal CA1 neurones. Brain Res Dev Brain Res 91(1):29-40.

DeLeon ER, Stoy GF, Olson KR (2012) Passive loss of hydrogen sulfide in biological experiments. Anal Biochem 421(1):203-207.

Diwakar L, Ravindranath V (2007) Inhibition of cystathionine- $\gamma$-lyase leads to loss of glutathione and aggravation of mitochondrial dysfunction mediated by excitatory amino acid in the CNS. Neurochem Int 50(2):418-426.

Dominy JE, Stipanuk MH (2004) New roles for cysteine and transsulfuration enzymes: production of $\mathrm{H}_{2} \mathrm{~S}$, a neuromodulator and smooth muscle relaxant. Nutr Rev 62(9):348-353.

Elrod JW, Calvert JW, Morrison J, Doeller JE, Kraus DW, Tao L, Jiao X, Scalia R, Kiss L, Szabo C, Kimura H, Chow CW, Lefer DJ (2007) Hydrogen sulfide attenuates myocardial ischemiareperfusion injury by preservation of mitochondrial function. Proc Natl Acad Sci U S A 104(39):15560-15565.

Enokido Y, Suzuki E, Iwasawa K, Namekata K, Okazawa H, Kimura H (2005) Cystathionine beta-synthase, a key enzyme for homocysteine metabolism, is preferentially expressed in the radial glia/astrocyte lineage of developing mouse CNS. FASEB J 19:1854-1856.

Erb A, Althaus M (2014) Actions of hydrogen sulfide on sodium transport processes across native distal lung epithelia (Xenopus laevis). PLoS One 9(6):e100971. http://dx.doi.org/10.1371/ journal.pone. 0100971 .

Evans JR, Bielefeldt K (2000) Regulation of sodium currents through oxidation and reduction of thiol residues. Neuroscience 101 (1):229-236.

Feng X, Zhou YL, Meng X, Qi FH, Chen W, Jiang X, Xu GY (2013) Hydrogen sulfide increases excitability through suppression of sustained potassium channel currents of rat trigeminal ganglion neurons. Mol Pain 9:4.

Furne J, Saeed A, Levitt MD (2008) Whole tissue hydrogen sulfide concentrations are orders of magnitude lower than presently accepted values. Am J Physiol Regul Integr Comp Physiol 295: R1479-R1485.

Ge SN, Zhao MM, Dong-Dong Wu DD, Chen Y, Wang Y, Zhu JH, Cai WJ, Zhu YZ, Zhu YC (2014) Hydrogen sulfide targets EGFR Cys797/Cys798 residues to induce $\mathrm{Na}^{+} / \mathrm{K}^{+}$-ATPase endocytosis and inhibition in renal tubular epithelial cells and Increase sodium excretion in chronic salt-loaded rats. Antioxid Redox Signal 21 (15):2061-2082.

Gerasimova EV, Yakovleva OV, Zefirov AL, Sitdikova GF (2013) Role of ryanodine receptors in the effects of hydrogen sulfide on transmitter release from the frog motor nerve ending. Bull Exp Biol Med 155:11-13.

Gerasimova E, Lebedeva J, Yakovlev A, Zefirov A, Giniatullin R, Sitdikova G (2015) Mechanisms of hydrogen sulfide $\left(\mathrm{H}_{2} \mathrm{~S}\right)$ action on synaptic transmission at the mouse neuromuscular junction. Neuroscience 303:577-585.

Han Y, Qin J, Chang X, Yang Z, Tang X, Du J (2005) Hydrogen sulfide may improve the hippocampal damage induced by recurrent febrile seizures in rats. Biochem Biophys Res Commun 327:431-436.

Hermann A, Sitdikova GF, Weiger T (2012a). In: Hermann A, Sitdikova GF, Weiger TM, editors. Gasotransmitters: physiology and pathophysiology. Berlin Heidelberg: Springer Press.

Hermann A, Sitdikova GF, Weiger T (2012b) Modulated by gasotransmitters - BK channels. In: Hermann A, Sitdikova GF, 
Weiger TM, editors. Gasotransmitters: physiology and pathophysiology -. Berlin Heidelberg: Springer Press. p. 163-201.

Hermann A, Sitdikova GF, Weiger T (2015) Oxidative stress and maxi calcium-activated potassium (BK) channels. Biomolecules 5 (3):1870-1911.

Ishigami M, Hiraki K, Umemura K, Ogasawara Yuki, Ishii Kazuyuki, Kimura H, Ogasawara Y, Ishii K, Kimura H (2009) A source of hydrogen sulfide and a mechanism of its release in the brain. Antioxid Redox Signal 11:205-214.

Janaky R, Varga V, Hermann A, Saransaari P, Oja SS (2000) Mechanisms of L-cysteine neurotoxicity. Neurochem Res 25(910):1397-1405.

Khademullah CS, Ferguson AV (2013) Depolarizing actions of hydrogen sulfide on hypothalamic paraventricular nucleus neurons. PLoS One 8(5):e64495.

Khalilov I, Dzhala V, Ben-Ari Y, Khazipov R (1999) Dual role of GABA in the neonatal rat hippocampus. Dev Neurosci 21:310-319.

Khalilov I, Holmes GL, Ben-Ari Y (2003) In vitro formation of a secondary epileptogenic mirror focus by interhippocampal propagation of seizures. Nat Neurosci 6:1079-1085.

Khazipov R, Leinekugel X, Khalilov I, Gaiarsa J, Ben-Ari Y (1997) Synchronization of GABAergic interneuronal network in CA3 subfield of neonatal rat hippocampal slices. J Physiol 498:763-772.

Kimura H (2000) Hydrogen sulfide induces cyclic AMP and modulates the NMDA receptor. Biochem Biophys Res Commun 267 (1):129-133.

Kimura H (2010) Hydrogen sulfide: from brain to gut. Antioxid Redox Signal 12:1111-1123.

Kimura Y, Kimura H (2004) Hydrogen sulfide protects neurons from oxidative stress. FASEB J 18(10):1165-1167.

Kimura Y, Goto Y, Kimura H (2010) Hydrogen sulfide increases glutathione production and suppresses oxidative stress in mitochondria. Antioxid Redox Signal 12:1-13.

Köhr G (2006) NMDA receptor function: subunit composition versus spatial distribution. Cell Tissue Res 326:439-446.

Kuksis M, Ferguson AV (2015) Actions of a hydrogen sulfide donor (NaHS) on transient sodium, persistent sodium, and voltagegated calcium currents in neurons of the subfornical organ. J Neurophysiol 114:1641-1651.

Kuksis M, Smith PM, Ferguson AV (2014) Hydrogen sulfide regulates cardiovascular function by influencing the excitability of subfornical organ neurons. PLoS One 9:e105772.

Leinekugel X, Medina I, Khalilov I, Ben-Ari Y, Khazipov R (1997) $\mathrm{Ca}^{2+}$ oscillations mediated by the synergistic excitatory actions of GABA(A) and NMDA receptors in the neonatal hippocampus. Neuron 18(2):243-255.

Linden DR, Sha L, Mazzone A, Stoltz GJ, Bernard CE, Furne JK, Levitt MD, Farrugia G, Szurszewski JH (2008) Production of the gaseous signal molecule hydrogen sulfide in mouse tissues. J Neurochem 106(4):1577-1585.

Luo Y, Liu X, Zheng Q, Wan X, Ouyang S, Yin Y, Sui X, Liu J, Yang X (2012) Hydrogen sulfide prevents hypoxia-induced apoptosis via inhibition of an $\mathrm{H}_{2} \mathrm{O}_{2}$-activated calcium signaling pathway in mouse hippocampal neurons. Biochem Biophys Res Commun 425(2):473-477.

Luo Y, Wu PF, Zhou J, Xiao W, He JG, Guan XL, Zhang JT, Hu ZL, Wang F, Chen JG (2014) Aggravation of seizure-like events by hydrogen sulfide: involvement of multiple targets that control neuronal excitability. CNS Neurosci Ther 20:411-419.

Malik R, Ferguson AV (2016) Hydrogen sulfide depolarizes neurons in the nucleus of the solitary tract of the rat. Brain Res 1633:1-9.

Martin GR, McKnight GW, Dicay MS, Coffin CS, Ferraz JG, Wallace $J L$ (2010) Hydrogen sulphide synthesis in the rat and mouse gastrointestinal tract. Dig Liver Dis 42(2):103-109.

Mason MJ, Simpson AK, Mahaut-Smith MP, Robinson HPC (2005) The interpretation of current-clamp recordings in the cell-attached patch-clamp configuration. Biophys J 88(1):739-750.

Mattson MP, Shea TB (2003) Folate and homocysteine metabolism in neural plasticity and neurodegenerative disorders. Trends Neurosci 26:137-1463.
McBean GJ (2007) Sulfur-containing amino acids. In: Lajtha A, Oja SS, Schousboe A, Pirjo Saransaari P, editors. Handbook of neurochemistry and molecular neurobiology amino acids and peptides in the nervous system. Berlin, Heidelberg: SpringerVerlag. p. 133-134.

Mitrukhina OB, Yakovlev AV, Sitdikova GF (2013) The effects of hydrogen sulfide on the processes of exo- and endocytosis of synaptic vesicles in the mouse motor nerve endings. Biochemistry (Moscow) 7(2):170-173.

Mustafina AN, Yakovlev AV, Gaifullina ASh, Weiger TM, Hermann A, Sitdikova GF (2015) Hydrogen sulfide induces hyperpolarization and decreases the exocytosis of secretory granules of rat $\mathrm{GH} 3$ pituitary tumor cells. Biochem Biophys Res Commun 465 (4):825-831.

Nardou R, Yamamoto S, Bhar A, Burnashev N, Ben-Ari Y, Khalilov I (2011) Phenobarbital but not diazepam reduces AMPA/kainate receptor mediated currents and exerts opposite actions on initial seizures in the neonatal rat hippocampus. Front Cell Neurosci 5:16.

Nowak L, Bregestovski P, Ascher P, Herbert A, Prachiantz A (1984) Magnesium gates glutamate-activated channels in mouse central neurons. Nature 307:462-465.

Olney JW, Zorumski C, Price MT, Labruyere J (1990) L-cysteine, a bicarbonate-sensitive endogenous excitotoxin. Science 248:596-599.

Pan JG, Hu HY, Zhang J, Zhou H, Chen L, Tang YH, Zheng Y (2010) Protective effect of hydrogen sulfide on hypoxic respiratory suppression in medullary slice of neonatal rats. Respir Physiol Neurobiol 171:181-186.

Perkins KL (2006) Cell-attached voltage-clamp and current-clamp recording and stimulation techniques in brain slices. J Neurosci Methods 154:1-18.

Puka-Sundvall M, Eriksson P, Nilsson M, Sandberg M, Lehmann A (1995) Neurotoxicity of cysteine: interaction with glutamate. Brain Res 705:65-70.

Reiffenstein RJ, Hulbert WC, Roth SH (1992) Toxicology of hydrogen sulfide. Annu Rev Pharmacol Toxicol 32:109-134.

Renga B (2011) Hydrogen sulfide generation in mammals: the molecular biology of cystathionine-beta-synthase (CBS) and cystathionine-gamma-lyase (CSE). Inflamm Allergy Drug Targets 10:85-91.

Rosenquist TH, Finnell RH (2001) Genes, folate and homocysteine in embryonic development. Proc Nutr Soc 60:53-61.

Sekiguchi F, Miyamoto Y, Kanaoka D, Ide H, Yoshida S, Ohkubo T, Kawabata A (2014) Endogenous and exogenous hydrogen sulfide facilitates T-type calcium channel currents in Cav3.2-expressing HEK293 cells. Biochem Biophys Res Commun 445:225-229.

Shibuya N, Kimura H (2013) Production of hydrogen sulfide from dcysteine and its therapeutic potential. Front Endocrinol (Lausanne) 4:87.

Shibuya N, Koike S, Tanaka M, Ishigami-Yuasa M, Kimura Y, Ogasawara $Y$ (2013) A novel pathway for the production of hydrogen sulfide from D-cysteine in mammalian cells. Nat Commun 4:1366.

Sitdikova GF, Weiger TM, Hermann A (2010) Hydrogen sulfide increases calcium-activated potassium (BK) channel activity of rat pituitary tumor cells. Pflugers Arch - Eur J Physiol 459:389-397.

Sitdikova GF, Yakovlev AV, Odnoshivkina YG, Zefirov AL (2011) Effects of hydrogen sulfide on the exo- and endocytosis of synaptic vesicles in frog motor nerve endings. J. Neurochem 5 (4):245-250.

Sitdikova GF, Fuchs R, Kainz V, Weiger TM, Hermann A (2014) Phosphorylation of BK channels modulates the sensitivity to hydrogen sulfide $\left(\mathrm{H}_{2} \mathrm{~S}\right)$. Front Physiol 12:431.

Tang G, Wu L, Wang R (2010) Interaction of hydrogen sulfide with ion channels. Clin Exp Pharmacol Physiol 37(7):753-763.

Tyzio R, Ivanov A, Bernard C, Holmes GL, Ben-Ari Y, Khazipov R (2003) Membrane potential of CA3 hippocampal pyramidal cells during postnatal development. J Neurophysiol 90:2964-2972.

Wang R (2012) Physiological implications of hydrogen sulfide: a Whiff exploration that blossomed. Physiol Rev 92(2):791-896. 
Wedmann R, Bertlein S, Macinkovic I, Böltz S, Miljkovic JL, Muñoz LE, Herrmann M, Filipovic MR (2014) Working with " $\mathrm{H}_{2} \mathrm{~S}$ ": facts and apparent artifacts. Nitric Oxide 41:85-96.

Whitfield NL, El Kreimier, Verdial FC, Skovgaard N, Kenneth R, Olson KR (2008) Reappraisal of $\mathrm{H}_{2} \mathrm{~S} /$ sulfide concentration in vertebrate blood and its potential significance in ischemic preconditioning and vascular signaling. Am J Physiol Regul Integr Comp Physiol 294(6):R1930-R1937.

Yakovlev AV, Koroleva KS, Valiullina FF, Khazipov RN (2013) Resting membrane potential of the rat ventroposteriomedial thalamic neurons during postnatal development. Biochemistry (Moscow) 7:207-212.

(Accepted 21 October 2016)

(Available online 27 October 2016) 